\title{
PHYSIOLOGICAL AND SENSORIAL ASPECTS OF PEACH FRUITS cv. Chimarrita DEPENDING ON THE SEASON AND MANAGEMENT OF GREEN PRUNING
}

\author{
Marcelo Dotto $^{1}$, Kelli Pirola ${ }^{2}$, Américo Wagner Junior ${ }^{2}$, Juliana Cristina Radaelli ${ }^{2}$, Luis Corrêa \\ Antunes $^{3} \&$ Idemir Citadin ${ }^{2}$
}

\begin{abstract}
${ }^{1}$ União de Ensino do Sudoeste do Paraná. E-mail: marcelodotto@ hotmail.com
${ }^{2}$ Universidade Tecnológica Federal do Paraná Campus Dois Vizinhos. E-mail: kelli_pirola1@ @otmail.com; americowagner@utfpr.edu.br; julianaradaelli@gmail.com; idemir@utfpr.edu.br

${ }^{3}$ EMBRAPA Pelotas-RS. E-mail: luis.antunes@embrapa.br
\end{abstract}

\section{ABSTRACT}

For quality peach production it is necessary to perform the correct management in all cultive processes. The objective of this work was to evaluate the time and the management of performing green pruning on the physiological and sensorial aspects of the peach fruits cv. Chimarrita. The work was carried out in an orchard in Dois Vizinhos (PR), during the 2011/2012 production cycle. The experimental design was a completely randomized $3 \times 3$ factorial scheme, season $\mathrm{x}$ types of pruning with 4 replicates. The seasons of green pruning were in the third, fourth and fifth week before harvest. The pruning techniques of green pruning were with the folding of the branches, pruning with the removal of the branch and control without any type of management related to pruning. Sensorial characteristics of the fruits and physiological of the plants were evaluated. It was observed with folding of the branches, fruit with higher qualityand when it was removed of the branches, independent of the time, fruits with increase in the red color.

Keywords: Prunus persica, fruits, cultural practice

\section{ÉPOCA E FORMA DE PODA VERDE SOBRE ASPECTOS FISIOLÓGICOS E SENSORIAIS DOS FRUTOS DE PESSEGUEIRO cv. Chimarrita}

\section{RESUMO}

Para produção de pêssego com qualidade é necessário realizar o manejo correto em todos as etapas de cultivo. O objetivo deste trabalho foi avaliar a época e a forma de executar a poda verde nos aspectos fisiológicos e sensoriais dos frutos de pessegueiro chimarrita. O trabalho foi conduzido em pomar no município Dois Vizinhos (PR), ciclo produtivo 2011/2012. O delineamento experimental 
utilizado foi inteiramente casualizado esquema fatorial 3 x 3, época e tipos de poda com 4 repetições. As épocas de realização da poda verde foram na terceira, quarta e quinta semana antes da colheita. Dentre as técnicas de manejo da poda verde, teve-se aquela com o dobramento dos ramos, poda com a retirada do ramo e testemunha sem qualquer tipo de manejo relacionado a poda. Foram avaliadas características sensoriais dos frutos e fisiológicas das plantas. Os melhores frutos foram observados com dobramento dos ramos e com maior coloração vermelha da casca foi com a retirada dos ramos, independente de época de realização.

Palavras-chave: Prunus persica, frutos, prática cultural

\section{INTRODUCTION}

The peach is highly valued as a table or industry fruit, both for its attractive color and for its sensory characteristics. The attractive and quality fruit for consumer makes possible the use of superior genetic materials launched by breeding programs, as well as of appropriate management practices that enable the plant to express its maximum genetic potential (ALCOBENDAS et al., 2012). However, it is still necessary to take into account climatic conditions related to temperature, dry or humid climates, low or high radiation and the soil for with good or poor drainage, and/or fertility (MARTÍNEZ-BALESTA et al., 2010).

Knowledge of fruit tree responses to environmental variations is of fundamental importance in order to establish good management under current conditions, aiming at improving fruit quality and maximizing productivity, which allows it to remain competitive in the market (Matias et al. 2011).

For good management it is important to proceed properly with fertilization and liming, conduction, phytosanitary treatments, fruit thinning and pruning.

Among the prunings it is highlighted the denominated green type, that is in the vegetative period of the plants, next to the harvest. It consists of the removal of badly positioned, diseased and/or broken branches, improving the radiation and aeration inside the plant canopy. It can be said that this practice is a determining factor to obtain quality fruits, since it provides improvements in the visual aspect of the same for its commercialization and the consumer usually acquires it by its external appearance. In addition, when properly carried out, it can reduce pruning management in the next productive cycle (BAVARESCO et al., 2008). In order to evaluate the effect of leaf pruning, it is important to evaluate the effect of nutrient and metabolic changes. 
However, although green pruning improves the radiation and aeration inside the canopy, it should be done with caution, since it can decrease the photosynthetic capacity of the plants by removing leaves, in addition to being able to alter the growth between aerial part/root. Thus, if poorly conducted it can cause serious damage to the next crop cycle. Thus, it is important to analyze the best way to apply it, as well as, the ideal time to obtain good quality fruits, without changing the productive load in the next cycles.

To try to avoid these problems one could test the realization of the folding of the chosen branches instead of removing them. Thus, the photosynthetic capacity could not be so reduced in the plant, maintaining a certain relation source $\mathrm{x}$ drain, necessary to obtain fruits of quality, besides assisting for incidence of light inside the canopy in order to reach the fruits, increasing consequently the synthesis of pigments that provide consumer acceptability. However, in order to verify this hypothesis, it is necessary to compare it with the usual green pruning and without such practice.

The objective of this work was to evaluate the time and the form of the green pruning on the physiological and sensorial aspects of the peach fruit.

\section{METHODOLOGY}

The work was conducted in a commercial orchard in the municipality of Dois Vizinhos, State of Paraná, Brazil, in the 2011/2012 peaches production cycle. This orchard was implanted in the 2008/2009 cycle. The experimental design was a completely randomized one, in a 3 x 3 factorial scheme, three seasons $\mathrm{x}$ three pruning forms, with 4 replications, each plot being 2 plants.

The seasons of green pruning were in the third, fourth and fifth week before harvest. Among the forms of management of green pruning, one was based on the removal cutting of the badly positioned branches in the interior and in the base of the plant, the broken branches and the ones that grew vertically; folding of the branches, with the same characteristics previously mentioned, by the difference of remaining attached to the plant, (without cuts); plants that did not undergo any type of green pruning. All other management practices were performed following the technical recommendation for peach tree cultivation (BRUCKNER, 2003).

Fruit weight (g), pulp firmness (pounds), sutural diameter, equatorial and polar diameters (mm), pulp $\mathrm{pH}$, total soluble solids content (SST) ( ${ }^{\circ}$ Brix), total sugars and reducing sugars $\left(\mathrm{mg} \mathrm{g}^{-1}\right)$, anthocyanins and flavonoids $\left(\mathrm{mg} \mathrm{g}^{-1}\right.$ ), total titratable acidity (ATT) (grams of malic acid per $100 \mathrm{ml}$ of juice) and the ATT/SST ratio, were evaluated. 
Physiological analyzes of the plants were also carried out thirty days after the last management practice, comparing leaflets of folded branches with those of normally developed branches. These measurements were always started at 9:30 a.m., using healthy leaves of the fully grown middle third of two plants per plot. The microclimatic conditions in the sample chamber were maintained constant during the readings in the different treatments, being $1100 \mu \mathrm{mol} \mathrm{m} \mathrm{m}^{-2} \mathrm{~s}^{-1}$ photosynthetically active radiation, ambient $\mathrm{CO}_{2}$ concentration (average of $383 \mu \mathrm{mol} \mathrm{CO}_{2} \mathrm{~mol}^{-1}$ ). The efficiency of water use $(\%), \mathrm{CO}_{2}$ assimilation rate $\left(\mu \mathrm{mol} \mathrm{CO} \mathrm{C}^{-2} \mathrm{~s}^{-1}\right)$, water conductance $\left(\mathrm{mol} \mathrm{H}_{2} \mathrm{O} \mathrm{m}^{-2} \mathrm{~s}^{-1}\right)$, intracellular concentration $\left(\mu \mathrm{mol} \mathrm{CO} 2 \mathrm{~mol}^{-1}\right)$, transpiration rate $\left(\mathrm{mmol} \mathrm{H}_{2} \mathrm{O} \mathrm{m}^{-2} \mathrm{~s}^{-1}\right)$, and foliar temperature $\left({ }^{\circ} \mathrm{C}\right)$. For this an open gas measurement system equipped with the LI-6400XT (LI-COR, Lincoln, Nebraska - USA) infrared gas analyzer (IRGA) and artificial red and blue light source used.

The data were submitted to the normality test of Lilliefors, and only the $\mathrm{pH}$ and pulp firmness variables did not required transformation. For the other variables, the data transformation was performed, applying the $\sqrt{ } x+1$ transformation. Subsequently, the data were submitted to analysis of variance, followed by the comparison test of averages using the SANEST program (ZONTA \& MACHADO, 1984).

\section{RESULTS AND DISCUSSION}

According to the results obtained, there was no interaction between the evaluated factors. Likewise, no significant effect of each factor was observed on fruit sensory variables related to total soluble solids, pH, flavonoids, suture, equatorial and polar diameters, firmness and fresh matter mass of each fruit (Tables 1 and 2), and in the plant physiology for water use efficiency, $\mathrm{CO}_{2}$ assimilation rate, intracellular $\mathrm{CO}_{2}$ concentration, leaf temperature (Table 3). In the total sugars content of the fruits there was a significant interaction between season $\mathrm{x}$ green pruning (Table 5).

On the other hand, it was possible to obtain a significant effect on how to perform green pruning in relation to SST/ATT, ATT, reducing sugar content, fruit anthocyanins, water conductance and transpiration rate of plants (Table 4).

The relationship between soluble solids and acidity may indicate flavor, showing the best palatability for in natura consumption (MAYER et al, 2008). For this relation, the highest values were recorded with the folding management of the branches (Table 4). Possibly, this occurred due to the branches when folded attached to the plant and, consequently, they remained with the production of photoassimilates, which were sent to the fruits and mainly, by transpiration and greater efficiency of the 
water conductance (Table 4), causing water to remain and be translocated efficiently, causing assimilates to quickly reach the fruits.

Table 1: Total soluble solids (SST) $\left({ }^{\circ}\right.$ Brix). pulp pH, flavonoids (mg. $\left.\mathrm{g}^{-1}\right)$, sutural diameters of peach fruits cv. Chimarrita, according to the management method of green pruning and season based in the weeks leading up to harvesting.

\begin{tabular}{ccccc}
\hline Practice/Week & SST & $\mathrm{pH}$ & Flavonoids & Sutural diameter \\
\hline Pruning / 5 & $12,91^{\mathrm{ns}}$ & $4,30^{\mathrm{ns}}$ & $40,70^{\mathrm{ns}}$ & $67,7^{\mathrm{ns}}$ \\
Pruning / 4 & 10,73 & 4,32 & 41,83 & 58,54 \\
Pruning / 3 & 11,01 & 4,10 & 41,04 & 59,17 \\
Folding / 5 & 10,93 & 4,09 & 44,82 & 58,25 \\
Folding / 4 & 10,39 & 4,35 & 38,52 & 59,09 \\
Foldinjg / 3 & 11,16 & 4,27 & 38,16 & 59,27 \\
NM $^{*}$ & 10,85 & 3,92 & 40,48 & 59,45 \\
\hline CV (\%) & 3,67 & 9,81 & 11,55 & 4,41 \\
\hline
\end{tabular}

${ }^{\mathrm{ns}}$ Not significative by the $\mathrm{F}$ test.

*NM: Not managed.

Table 2: Equatorial and polar diameter (mm), firmness (pounds) and fresh dry matter (FDM) of the fruit (g) of peach fruits cv. Chimarrita, according to the management method of green pruning and season based in the weeks leading up to harvesting.

\begin{tabular}{ccccc}
\hline Practice/Week & Equatorial diameter & Polar diameter & Firmness & FDM \\
\hline Pruning / 5 & $63,69^{\text {ns }}$ & $64,93^{\text {ns }}$ & $4,72^{\text {ns }}$ & $125,38^{\text {ns }}$ \\
Pruning / 4 & 55,90 & 57,46 & 5,91 & 106,97 \\
Pruning / 3 & 56,32 & 57,80 & 5,49 & 108,10 \\
Folding / 5 & 56,22 & 57,07 & 4,92 & 107,15 \\
Folding / 4 & 56,57 & 56,82 & 5,02 & 111,46 \\
Foldinjg / 3 & 56,22 & 58,0 & 4,08 & 112,46 \\
NM* & 57,28 & 58,0 & 5,62 & 111,05 \\
\hline CV (\%) & 4,65 & 4,44 & 29,61 & 6,82 \\
\hline
\end{tabular}

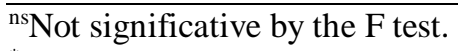

*NM: Not managed. 
Table 3: Water efficiency use (\%), assimilation rate of $\mathrm{CO}_{2}\left(\mu \mathrm{mol} \mathrm{CO}_{2} \mathrm{~m}^{-2} \mathrm{~s}^{-1}\right)$, internal $\mathrm{CO}_{2}$ concentration $\left(\mu \mathrm{mol} \mathrm{CO}_{2} \mathrm{~mol}^{-1}\right.$ ), leaf temperature $\left({ }^{\circ} \mathrm{C}\right)$ of peach fruits $\mathrm{cv}$. Chimarrita, according to the management method of green pruning and season based in the weeks leading up to harvesting.

\begin{tabular}{ccccc}
\hline Practice/Week & Water efficiency & $\mathrm{CO}_{2}$ assimilation rate & $\begin{array}{c}\text { Internal concentration } \\
\text { of } \mathrm{CO}_{2}\end{array}$ & Leaf temperature \\
\hline Pruning / 5 & $0,52^{\mathrm{ns}}$ & $875,62^{\mathrm{ns}}$ & $265,03^{\mathrm{ns}}$ & $26,26^{\mathrm{ns}}$ \\
Pruning / 4 & 0,42 & 598,66 & 260,69 & 26,86 \\
Pruning / 3 & 0,47 & 3397,37 & 277,03 & 26,19 \\
Folding / 5 & 0,53 & 9,32 & 267,21 & 27,12 \\
Folding / 4 & 0,51 & 2924,71 & 249,06 & 26,79 \\
Folding / 3 & 0,54 & 8,84 & 280,43 & 26,33 \\
$\mathrm{NM}^{*}$ & 0,49 & 11,82 & 267,19 & 27,00 \\
\hline $\mathrm{CV}(\%)$ & 2,97 & 177,40 & 5,51 & 2,48 \\
\hline
\end{tabular}

${ }^{n}$ Not significative by the $\mathrm{F}$ test.

*NM: Not managed.

Table 4: SST/ATT relation, acidity ( $\mathrm{g}$ of malic acid per $100 \mathrm{ml}$ of juice), reducing sugar content (RSC) and anthocyanins $\left(\mathrm{mg} \mathrm{g}^{-1}\right)$ of fruits, water conductance (WC) $\left(\mathrm{mol} \mathrm{H}_{2} \mathrm{O} \mathrm{m}^{-2} \mathrm{~s}^{-1}\right)$ and transpiration rate (TR) $\left(\mathrm{mmol} \mathrm{H}_{2} \mathrm{O} \mathrm{m}^{-2} \mathrm{~s}^{-1}\right)$ of peach fruits $\mathrm{cv}$. Chimarrita, according to the management method of green pruning.

\begin{tabular}{lcccccc}
\hline $\begin{array}{l}\text { Management } \\
\text { method }\end{array}$ & SST/ATT & Acidity & RSC & Anthocyanins & WC & TR \\
\hline Pruning & $2,84 \mathrm{~b}^{*}$ & $4,31 \mathrm{a}$ & $32,42 \mathrm{~b}$ & $2,93 \mathrm{a}$ & $0,21 \mathrm{a}$ & $2,72 \mathrm{a}$ \\
Folding & $3,55 \mathrm{a}$ & $3,08 \mathrm{~b}$ & $30,64 \mathrm{~b}$ & $1,38 \mathrm{~b}$ & $0,19 \mathrm{a}$ & $1,82 \mathrm{~b}$ \\
NM $^{*}$ & $2,85 \mathrm{~b}$ & $3,85 \mathrm{ab}$ & $37,05 \mathrm{a}$ & $4,34 \mathrm{a}$ & $0,12 \mathrm{~b}$ & $2,64 \mathrm{a}$ \\
\hline $\mathrm{CV}(\%)$ & 8,60 & 10,31 & 9,20 & 22,56 & 3,00 & 9,48 \\
\hline
\end{tabular}

*Averages with different letters, lowercase in the column, differ significantly within themselves by Duncan's test $(\mathrm{p}=0,5)$. *NM: Not managed.

The anthocyanin content of the fruits showed superiority in the plants in which the branches were pruned and those of unmanaged plants in relation to the folded branches (Table 4).

Some studies have shown that the availability of additional light to the plants, obtained with green pruning, intensifies the red coloration in the epidermis of peaches (TREVISAN et al., 2006; TREVISAN et al., 2008). 
The control of the vegetative development of the plants, by the green pruning can be fundamental to guarantee the productivity of the orchard and to optimize the quality of the fruits like coloring among other attributes (CLINE et al., 2008).

Possibly the practice of folding the branches decreased the incidence of light inside the canopy, .This folding was directed to the center of the canopy, aiming at avoiding the burning of the branches common in peach trees, being that this fact may have favored to inferior values seen for anthocyanins. This hypothesis can be verified when the transpiration rate is analyzed, since plants with detached branches and with unmanaged branches show the highest transpiration averages (Table 3).

The rate of transpiration is controlled by environmental factors that govern stomatal opening and closed, among which are temperature and lightness.

Therefore, it is believed that with the higher incidence of radiation inside these plants, whose branches were detached or not managed, allowed a higher temperature inside the canopy, favoring a higher rate of transpiration, since the folding of the branch allowed for higher shading. In addition, it is suspected that with the folding of the branches, these provided the leaves stomata closed in response to the stress caused and consequently less perspiration. This may have impaired the absorption of nutrients required for the metabolism that trigger the reddish coloring.

Another hypothesis works based on the results obtained regarding the assimilation and internal concentration of $\mathrm{CO}_{2}$, which presented averages statistically similar in the three managements adopted. This leads us to suppose that with the folding of the branches the higher production of ethylene was triggered in relation to those of plants with the pruning by the remotion. This consequently provided the largest difference between higher sugar yield or higher anthocyanin synthesis, respectively.

As for the acidity of the fruits, it was verified that those obtained from plants in which the branches were folded had lower acidity, with an average of 3,08, being this a statistically similar value of the plants in which the green pruning was not carried out, whose average was of 3,85 (Table 3).

For the $\mathrm{pH}$ of the fruit pulp, values above 4.00 and below 4.30 were obtained, except for those from pruned plants, which presented an average of 3.92. In a study carried out with the cultivar Chimarrita on different rootstocks, where they did not obtain statistical differences, these values were between 4.00 and 4.20 , corroborating with the data observed in this work for the same cultivar (COMIOTTO et al., 2013).

For the reducing sugar content (Table 1), fruits of unmanaged plants presented higher averages in comparison to those pruned realized. It is believed that with the of green pruning management, 
regardless of the technique used, there was an increase in the metabolic activity of these plants, mainly as regards the respiratory process to generate more energy production necessary for maintenance and development of these a posteriori, which led to higher consumption of reducing sugars, such as glucose and fructose, required for the formation of pyruvate. The pyruvate is a product of glycolysis, and its production is necessary for the Krebs cycle to occur in sequence, the site of greater energy production of the plant by the respiratory process (TAIZ \& ZEIGER, 2013).

In part this can be proven by the water conductance values, which were higher in these treatments, which facilitated the flow of the sap inside these plants, using the sugars more quickly by the fruits (Table 4). The relationship between soluble solids and acidity may indicate flavor, showing the best palatability for in natura consumption (MAYER et al., 2008). For this relation, the highest values were recorded with the foliar management of the branches (Table 4).

Table 5: Total of sugars $\left(\mathrm{mg} \mathrm{g}^{-1}\right)$ of peach fruits $\mathrm{cv}$. Chimarrita, according to the management method of green pruning.

\begin{tabular}{|c|c|c|c|}
\hline \multirow[b]{2}{*}{ Management method } & \multicolumn{3}{|c|}{ Season } \\
\hline & $\begin{array}{c}\text { Five weeks before } \\
\text { harvesting }\end{array}$ & $\begin{array}{c}\text { Four weeks before } \\
\text { harvesting }\end{array}$ & $\begin{array}{c}\text { Three weeks before } \\
\text { harvesting }\end{array}$ \\
\hline Pruning & 28,57 a $\mathrm{A}$ & 24,68 b B & $27,67 \mathrm{~b} \mathrm{~A}$ \\
\hline Folding & 31,18 a $\mathrm{A}$ & 28,63 a $\mathrm{A}$ & $25,63 \mathrm{~b} \mathrm{~B}$ \\
\hline $\mathrm{NM}^{*}$ & $30,28 \mathrm{a} \mathrm{A}^{*}$ & 30,28 a A & 30,28 a A \\
\hline $\mathrm{CV}(\%)$ & & 2,91 & \\
\hline
\end{tabular}

${ }^{*}$ Averages with different letters, lowercase in the column, differ significantly within themselves by Duncan's test $(p=0,5)$. *NM: Not managed.

Thus, in the five weeks before harvest there was no significant effect of the practices to obtain higher or lower sugar content of the fruits (Table 4). On the other hand, in the four weeks, both the folding and the no management provided superiority for this variable. In the three weeks, the superiority was obtained only with fruits harvested from plants not submitted to the management of green pruning, which already demonstrates that such management should not be performed very close to the harvest, since it interferes negatively on the quality of the fruit (Table 4). This was verified in practice with the folding of the branch, since, the highest averages of total sugars were from fruits whose management was carried out in the fifth and fourth week before harvest. 
High soluble solids contents are very important for the fruit consumption, as well as the use in the candy industry, increasing the flavor of these fruits (RAMOS et al., 2010).

However, if the pruning is chosen with the removal of the branch this should be done in the fifth or third week before harvest (Table 5).

\section{CONCLUSION}

The practice of folding of the branch makes possible an improvement in the flavor of the Chimarrita peaches, with the pruning had obtaining of fruits with higher reddish coloration, that is, better appearance.

The time of accomplishment of such practices does not influence the quality of the fruits, but could adopt the fifth and fourth week for the technique of folding and the fifth and third week for pruning with removal of the branches.

\section{REFERENCES}

ALCOBENDAS, R.; MIRÁS-AVALOS, J.M.; ALARCÓN, J.J.; PEDRERO, F.; NICOLÁS, E. 2012. Combined effects of irrigation, crop load and fruit position on size, color and firmness of fruits in an extra-early cultivar of peach. Scientia Horticulturae, Amsterdã, v.142, p. 128-135.

BAVARESCO, L. et al. 2008. Effect of leaf removal on grape yield, berry composition, and stilbene concentration. American Journal of Enology and Viticulture, Davis, v.59, n.3, p.292-298.

BRUCKNER, C. H. 2003. Principais tipos de poda empregados em fruteiras tropicais. In: ZAMBOLIM, L. Manejo integrado: produção integrada; fruteiras tropicais; doenças e pragas, Viçosa, $587 \mathrm{p}$.

CLINE, J.A.; EMBREE, C.G.; HEBB, J.; NICHOLS, D.S. 2008. Performance of prohexadione-calcium on shoot growth and fruit quality of apple - effect of spray surfactants. Canadian Journal of Plant Science, Ontario-Burlington v.88, p.165-174.

COMIOTTO, A.; FACHINELlO, J. C.; HOFFMANN, A.; GALARÇA, S. P.; MACHADO, N. P.; PREZOTTO, M. E.; HASS, L. B. 2013. Desenvolvimento, produção e qualidade dos frutos de pessegueiros enxertados sobre diferentes porta-enxertos. Semina: Ciências Agrárias, Recife, v. 34, n. 6, p. 3553-3562.

MARTÍNEZ-BALlESTA, M.C.; ALCARAZ-LÓPEZ, C.; MURIES, B.; MOTA-CADENAS, C.; CARVAJAL, M. 2010. Physiological aspects of rootstock-scion interactions. Scientia Horticulturae, Amsterdã, v.127, p.112-118. 
MATIAS, R. G. P.; BRUCKNER, C. H.; SANTOS, C. E. M. DOS; SANTOS, D. C.F.D. DOS; SILVA, D. F. P. 2011. Seleção de genótipos de pessegueiro com base na necessidade de frio para germinação das sementes. Revista Brasileira de Fruticultura, Jaboticabal, v. 33, n.2, p. 571-576.

MAYER, N. A.; MATTIUZ, B.; PEREIRA, F.M. 2008. Qualidade pós-colheita de pêssegos de cultivares e seleções produzidos na microrregião de Jaboticabal-SP. Revista Brasileira de Fruticultura, Jaboticabal, v. 30, n. 3, p. 616-621.

RAMOS, D. P.; SILVA, A. C.; LEONEL, S.; COSTA, S. M.; DAMATTO JÚNIOR, E. R.; 2010. Produção e qualidade de frutos da goiabeira 'Paluma', submetida à diferentes épocas de poda em clima subtropical. Revista Ceres, Viçosa, v. 57, n.5, p. 659-664.

RETAMALES, J. B. 2011. World temperate fruit production: characteristics and challenges. Revista Brasileira de Fruticultura, Jaboticabal, v. 33, p. 121-130.

TAIZ, L.; ZEIGER, E. 2013. Fisiologia Vegetal, 5ª Ed. Porto Alegre, Artmed. 918p.

TOMAZ, Z.F. P.; LIMA, C. S. M.; GONÇALVES, M. A.; RUFATO, L.; RUFATO, A. D. R. 2010. Crescimento vegetativo, floração e frutificação efetiva do pessegueiro 'Jubileu' submetido a diferentes comprimentos de interenxertos. Pesquisa Agropecuária Brasileira, Brasília, v.45, n.9, p.973-979.

TREVISAN, R.; HERTER, F.G.; COUTINHO, E.F.; GONÇALVES, E.D.; SILVEIRA, C.A.P.; FREIRE, C.J. DA S. 2006. Uso de poda verde, plásticos refletivos, anti-transpirante e potássio na produção de pêssegos. Pesquisa Agropecuária Brasileira, Brasília, v.41, n.10, p.1485-1490.

TREVISAN, R.; GONÇALVES, E. D.; GONÇALVES, R. DA S.; ANTUNES, L. E. C.; HERTER, F. G. 2008. Influência do plástico branco, poda verde e amino quelant ${ }^{\circledR}-\mathrm{K}$ na qualidade de pêssegos 'Santa Áurea'. Bragantia. Campinas, v.67, n.1, p. 243-247.

ZONTA, E.P.; MACHADO, A.A. 1984. Sanest - Sistema de Análise Estatística para Microcomputadores. UFPel, Pelotas, 75p. 